\title{
Хірургічна тактика лікування гострого некротичного панкреатиту
}

Мета роботи: оцінити ефективність розробленої хірургічної тактики лікування гострого некротичного панкреатиту. Матеріали і методи. Проведений аналіз результатів лікування 317 хворих на гострий некротичний панкреатит, в яких протягом 2013-2019 рр. використовували запропоновану тактику проведення хірургічних втручань. Для оцінки ефективності лікування вивчали вперше виявлену органну недостатність після операції, тривалість інтенсивної терапії, післяопераційні ускладнення та летальність.

Результати досліджень та їх обговорення. Застосовували покрокову тактику хірургічного лікування, яка розпочиналася 3 діапевтичних транскутанних втручань у 48,2 \% та ендоскопічних - у 46,2 \% спостережень. Транскутанні втручання супроводжувалися меншою частотою ускладень у хворих із гострими некротичними скупченнями, а ендоскопічні - у пацієнтів із відмежованими вогнищами панкреатичного некрозу. Широкі лапаротомні некрсеквестректомії виконані в 14,5 \% спостережень після 4 тижня від початку захворювання. Загальна летальність становила 3,5 \%, післяопераційна - 6,5 \%.

Використання покрокової хірургічної тактики лікування хворих на гострий некротичний панкреатит зменшує потребу в широких лапаротомних некрсеквестректоміях та сприяє зниженню рівня післяопераційних ускладнень.

Ключові слова: гострий некротичний панкреатит; мініінвазивні втручання; ехо-відеоендоскопія; покрокова тактика.

Постановка проблеми і аналіз останніх досліджень та публікацій. Частота гострого панкреатиту щорічно зростає на 2,5-3,1 \% і коливається в межах від 15 до 80 випадків на 100000 населення в країнах Європи та Північної Америки [1]. В основі захворювання лежить розвиток первинноасептичного гострого запального процесу в підшлунковій залозі, парапанкреатичних тканинах в результаті ферментного пошкодження ацинарної паренхіми з подальшим формуванням вогнищ некрозу. Це пошкодження характеризується переходом від місцевої до системної запальної реакції, супроводжується різноманітними розладами, що спричиняють функціональну недостатність внутрішніх органів з можливим виникненням синдрому поліорганної недостатності. В подальшому, за несприятливого перебігу захворювання, до асептичного запалення приєднується інфекція. Незважаючи на прогрес у діагностиці, консервативному і хірургічному лікуванні, летальність при тяжких формах ГНП залишається високою і коливається в межах 15-45 \% [2, 3]. Водночас погляди на місце, роль та методи хірургічних втручань при ГНП значно різняться, відсутня єдина точка зору щодо показань до використання мініінвазивних методів лікування та лапаротомної некрсеквестректомії залежно від термінів захворювання, розповсюдження, характеру і локалізації патологічних вогнищ захворювання [4-6].

Мета роботи: розробити хірургічну тактику лікування різних морфологічних форм гострого некротичного панкреатиту та оцінити її ефективність.
Матеріали і методи. Проведено аналіз результатів лікування 317 хворих на ГНП, що лікувалися у ДУ “Національний інститут хірургії та трансплантології ім. О. О. Шалімова” та ЛШМД м. Чернівці, в яких протягом 2013-2019 років застосовували покрокову хірургічну тактику з переважним використанням мініінвазивних технологій. Серед обстежених пацієнтів жінок було 145 (45,7 \%), чоловіків - 172 (54,3 \%), віком від 18 до 78 років (середній вік становив $48 \pm 1$ рік). Діагноз ГНП встановлювали на основі анамнезу, клінічної картини, даних лабораторних (амілаза крові і діастаза сечі) та інструментальних (ультразвукового дослідження та контрастно підсиленої комп’ютерної томографії) методів дослідження. Ступінь тяжкості ГНП оцінювали згідно 3 рекомендаціями групи із перегляду класифікації гострого панкреатиту (Атланта, 1992) інтернаціональним консенсусом у 2012 році [7] за наявності транзиторної або постійної ОН та за шкалою APACHE II (Acute Physiology and Chronic Health Evaluation II). Для визначення ОН оцінювали функції дихальної, серцево-судинної систем i нирок за модифікованою шкалою Marshall, неврологічну недостатність за шкалою ком Глазго [6]. Діагностику інфікування вогнищ панкреонекрозу проводили за ознаками системної запальної відповіді, даними комп’ютерної томографії, бактеріологічного дослідження, позитивним прокальцитоніновим або пресепсиновим тестом [8]. Всім хворим проводили індивідуально підібрану консервативну терапію, основними принципа- 
ми якої були: знеболювання, корекція порушень центральної гемодинаміки та периферійного кровообігу, раннє ентеральне харчування, адекватне білково-енергетичне забезпечення, профілактика гнійної інфекції, пригнічення секреторної активності підшлункової залози, дезінтоксикаційна терапія, корекція імунних розладів, профілактика утворення стресових виразок, гепатопротекція $[9,10]$. Для оцінки ефективності хірургічного лікування хворих на ГНП використовували: вперше виявлену післяопераційну органну недостатність, тривалість інтенсивної терапії після операції, інфекційні і післяопераційні ускладнення, післяопераційну летальність.

Результати досліджень та їх обговорення. В усіх фазах ГНП лікування розпочинали з консервативної терапії, обсяг якої визначався тяжкістю стану при госпіталізації та ризиком розвитку ускладнень [8].

Хірургічне лікування проводили послідовно, в якості першого кроку застосовували діапевтичні транскутанні або ендоскопічні втручання залежно від локалізації та морфологічної характеристики патологічних вогнищ.

У пацієнтів із гострими некротичними скупченнями перевагу віддавали транскутанним пункціям та встановленню силіконових дренажів діаметром 10-12 Fr під контролем УЗД, які при активному введенні в 81,1 \% пацієнтів були остаточним методом інвазивного лікування. Ехо-контрольовані ендоскопічні втручання застосовували в якості початкового інвазивного лікування в 69 пацієнтів із відмежованими вогнищами панкреатичних некрозів при їх приляганні до шлунка або ДПК. Ефективність методу склала 87,2 \%.

В післяопераційному періоді всім пацієнтам проводили етіотропну антибіотикотерапію за результатами регулярного бактеріологічного дослідження некротичних мас, ефективність якої оцінювали за активністю ССЗВ та за динамікою змін біологічних маркерів - С-реактивного протеїну, прокальцитоніну та пресепсину. При застосуванні транскутанних методів потреба в повторних втручаннях виникла в 64,5 \% спостережень, а при використанні ендоскопічного доступу - в 21,3 \% $(\mathrm{p}<0,05)$. Причиною їх виконання було недостатнє дренування некротичних мас та прогресування гнійно-запального процесу. Чинниками, що сприяли неефективності діапевтичних втручань, були ураження більше 30 \% ПЗ, наявність декількох некротичних вогнищ та їх великий об'єм із переважанням твердого вмісту. При недостатньо ефектив- ному дренуванні некротичного вмісту розширяли канал, по якому був введений дренаж, та замінювали його на більший за діаметром. При великих розмірах патологічних вогнищ у 10 спостереженнях використовували альтернативний (ендоскопічний або транскутанний, відповідно) доступ для повторного діапевтичного втручання. Одночасно відповідно до результатів антибіотикограм проводили корекцію антибактеріальної терапії.

Тільки при неефективності діапевтичних методів переходили до наступного, більш інвазивного кроку - застосування мініінвазивних некрсеквестректомій. У пацієнтів із гострими некротичними скупченнями перевагу надавали позаочеревинному доступу до уражених ділянок, для чого у 8 пацієнтів використовували люмботомну відео-контрольовану санацію за допомогою нефроскопа. За наявності відмежованих патологічних вогнищ, що прилягали до шлунка або ДПК, у 23 випадках застосовували ендоскопічну некрсеквестректомію під ехо-ендоскопічним контролем. Втручання проводили індивідуалізовано: при незначній кількості твердого компоненту в 7 спостереженнях некресквестретомію закінчували введенням двох двобічних дренажів типу pig-tale. За наявності великої кількості гнійних мас в 8 осіб у порожнину вводили цистоназальний зонд, через який підключали систему для безперервного лаважу фізіологічним розчином у післяопераційному періоді. При недостатній щільності оточуючої капсули та великій кількості детриту нами вперше у 8 пацієнтів застосовано саморозправляльні покриті металеві стенти для виконання адекватної та безпечної некрсеквестректомії. Вже після першого ендоскопічного втручання спостерігалося клінічне покращання із зменшенням ознак ССЗВ та $\mathrm{OH}$ в усіх випадках. У 26 пацієнтів із поширеними ураженнями ПЗ та запливами в заочеревинний простір ми вперше застосували комбінований ретроперіонеально-відеоендоскопічний доступ, в якому одночасно використовуються переваги ендоскопічного та люмботомного відеоконтрольованого методів некрсеквестректомії. На першому етапі під УЗД контролем встановлювали транскутанний дренаж, на другому - за допомогою еховідеоендоскопа проводили пункцію утворення через стінку шлунка або дванадцятипалої кишки та, за необхідності, виконували його внутрішнє дренування з використанням пластикових або металевих стентів. Незважаючи на тяжкість та поширеність ураження, метод виявився високоефективним і у 92 \% пацієнтів при його використанні не виникало необхідності в подальших втручаннях. 
При неможливості застосування вищеперерахованих втручань або їх недостатньої ефективності переходили до наступного кроку, а саме, до виконання відкритої лапаротомної некрсеквестректомії. У 12 пацієнтів із нагноєними відмежованими вогнищами панкреонекрозу невеликих (до 5-7 см в діаметрі) розмірів використовували селективні відкриті втручання. Необхідність у більш інвазивному лікуванні виникла тільки в двох пацієнтів. Широка лапаротомна панкреатонекрсеквестректомія виконана в 46 (14,5 \%) пацієнтів основної групи. В 40 пацієнтів втручання виконували після застосування діапевтичних транскутанних або ендоскопічних втручань та були останнім етапом в запропонованому нами покроковому підході хірургічного лікування ГНП. У 6 осіб, яких госпіталізували або переведені з інших лікувальних закладів у терміни після 4 тижня від початку захворювання та мали поширені нагноєнні відмежовані ураження із клінічною картиною сепсису, виконували лапаротомні втручання в якості першого та остаточного етапу хірургічного втручання (табл.).

Таблиця. Ефективність етапів хірургічного лікування хворих на гострий некротичний панкреатит

\begin{tabular}{|c|c|c|}
\hline \multirow{2}{*}{ Етапи хірургічного лікування } & \multicolumn{2}{|c|}{$\begin{array}{l}\text { Кількість оперованих пацієнтів, n, } \\
\text { (виконання лапаротомії, \%) }\end{array}$} \\
\hline & $\begin{array}{l}\text { гострі некротичні } \\
\text { скупчення }\end{array}$ & $\begin{array}{c}\text { відмежовані вогнища } \\
\text { некрозу }\end{array}$ \\
\hline $\begin{array}{l}\text { Діапевтичні втручання, в т. ч.: } \\
\text { - транскутанні } \\
\text { - ендоскопічні } \\
\text { - комбіновані }\end{array}$ & $\begin{array}{l}37(18,9) \\
15(26,6) \\
5(20)\end{array}$ & $\begin{array}{c}55(29,9) \\
54(7,4) \\
6(0)\end{array}$ \\
\hline $\begin{array}{l}\text { Мініінвазивні некрсеквестректомії в т. ч.: } \\
\text { - транслюмбальні під контролем нефроскопа } \\
\text { - ехо-відеоендоскопічні втручання } \\
\text { - ретроперитонеального-відеоендоскопічний доступ }\end{array}$ & $\begin{array}{c}4(0) \\
- \\
4(26,7)\end{array}$ & $\begin{array}{l}10(10,0) \\
23(13,0) \\
12(0)\end{array}$ \\
\hline $\begin{array}{l}\text { Відкриті некрсеквестректомії, в т. ч.: } \\
\text { - через мінілапаротомію } \\
\text { - через мінілюмботомію } \\
\text { - широкі лапаротомні }\end{array}$ & $\begin{array}{c}- \\
- \\
8(37,5)\end{array}$ & $\begin{array}{c}7(14,3) \\
5(20,0) \\
38(10,5)\end{array}$ \\
\hline
\end{tabular}

У післяопераційному періоді ускладнення спостерігалися в 28,3 \% і включали нові випадки ОН в 7 спостереженнях, арозивні кровотечі в 4 випадках, панкреатичні та дуоденальні нориці в 6 осіб. Загальна летальність становила 3,5 \%, після застосування широких лапаратомних некрсеквестректомій - 6,5 \%.

Висновки. 1. Хірургічна тактика лікування гострого некротичного панкреатиту повинна враховувати морфологічну форму захворювання та базуватися на послідовному (step-up) застосуванні оперативних втручань. В якості першого кроку слід використовувати діапевтичні втручання, наступного - методи мініінвазивної некрсеквестректомії і лише при їх неефективності доцільно проводити відкриті лапаротомні втручання.

2. Транскутанні мініінвазивні втручання під ультразвуковим контролем є оптимальним методом початкового хірургічного лікування в пацієнтів 3 ускладненими гострими некротичними скупченнями (до 4 тижня від початку гострого некротич- ного панкреатиту): при їх застосуванні не спостерігався розвиток післяопераційних ускладнень, потреба в лапаротомних операціях виникла в 19,8 \%.

3. У хворих із відмежованими вогнищами панкреонекрозу (після 4 тижня захворювання) більш ефективними $є$ ендоскопічні втручання, використання яких було остаточним у 94,4 \% випадках.

4. Застосування запропонованої хірургічної тактики покрокового (step-up) використання мініінвазивних втручань забезпечило зменшення потреби в широких лапаротомних некрсеквестректомій до 14,5 \% та відтермінувати їх виконання на строки після 4 тижня від початку захворювання у 82,6 \% оперованих пацієнтів, що сприяло зниженню частоти розвитку післяопераційної органної недостатності до 15,2 \% та післяопераційної летальності - до 6,5 \%.

Перспектива подальших досліджень. Перспективним вважаємо розробку нових методів мініінвазивних оперативних втручань при гострому некротичному панкреатиті. 


\section{З ДОСВІДУ РОБОТИ}

\section{СПИСОК ЛІТЕРАТУРИ}

1. Burden of gastrointestinal disease in the United States: 2012 update / A. F. Peery, E. S. Dellon, J. Lund [et al.] // Gastroenterology. - 2012. - Vol. 143 (5). - P. 1179-1187.

2. Результати хірургічного лікування парадуоденального (groove) панкреатиту / О. Ю. Усенко, В. М. Копчак, I. В. Хомяк [та ін.] // Клінічна хірургія. - 2019. - Т. 85 (11). - С. 5-8. 3. Хірургічне лікування хворих з гострим біліарним панкреатитом та жовчною гіпертензією / О. І. Дронов, І. Л. Насташенко, Я. М. Сусак [та ін.] // Клінічна хірургія. - 2018. T. 85 (4). - C. 5-8.

4. Лікувально-діагностична тактика при рідинно-кістозних утвореннях підшлункової залози / В. В. Бойко, В. М. Лихман, О. М. Шевченко [та ін.] // Клінічна хірургія. - 2019. - Т. 86 (3). - C. 3-6.

5. Treatment of necrotizing pancreatitis: redefining the role of surgery / G. Alsfasser, F. Schwandner, A. Pertschy [et al.] // World J. Surg. - 2012. - Vol. 36 (5). - P. 1142-1147.

6. Working Group IAP/APA Acute Pancreatitis Guidelines. IAP/
APA evidence-based guidelines for the management of acute pancreatitis // Pancreatology. - 2013. - Vol. 13 (Suppl. 1). - P. 1-15. 7. Classification of acute pancreatitis 2012: revision of the Atlanta classification and definitions by international consensus / P. A. Banks, T. L. Bollen, C. Dervenis [et al.] // Gut. - 2013. Vol. 62 (1). - P. 102-111.

8. Utility of Presepsin for diagnosis of infected acute necrotizing pancreatitis // JOP. J. Pancreas. (Online). - 2019. - Vol. 20 (2). - P. 67-71.

9. Хірургічне лікування хворих з приводу хронічного панкреатиту з біліарною гіпертензією / I. М. Шевчук, В. І. Пилипчук, А. Д. Хруник, С. М. Гедзик // Клінічна хірургія. 2017. - № 8. - С. 27-30.

10. Саволюк С. І. Оцінка якості життя хворих похилого та старечого віку після мініінвазивних оперативних втручань 3 приводу гострого калькульозного холециститу та холедохолітіазу / С. І. Саволюк, Б. В. Свиридюк, О. В. Іванко // Клінічна хірургія. - 2018. - Т. 85 (9). - С. 15-18.

\section{REFERENCES}

1. Peery, A.F., Dellon, E.S., Lund, J., Crockett, S.D., McGowan C.E., \& Bulsiewicz, W.J. (2012). Burden of gastrointestinal disease in the United States, 2012 update. Gastroenterology, 143 (5), 1179-1187.

2. Usenko, O.Y., Kopchak, V.M., Khomiak, I.V., Khomiak, A.I., Malik, A.V. (2019). Rezultaty khirurhichnoho likuvannia paraduodenalnoho (groove) pankreatytu [Results of surgical treatment of paraduodenal (groove) pancreatitis]. Klinichna khirurhiia - Clinical Surgery, 85 (11), 5-8 [in Ukrainian].

3. Dronov, O.I., Nastashenko, I.L., Susak, Ya.M., Tsymbaliuk, R.S., Tiuliukin, I.O. (2018). Khirurhichne likuvannia khvorykh z hostrym biliarnym pankreatytom ta zhovchnoiu hipertenziieiu [Surgical treatment of patients, suffering an acute biliary pancreatitis and biliary hypertension]. ]. Klinichna khirurhiia - Clinical Surgery, 85 (4), 5-8 [in Ukrainian].

4. Boiko, V.V., Lykhman, V.M., Shevchenko, O.M., Merkulov, A.O., \& Polikov, H.O. (2019). Likuvalno-diahnostychna taktyka pry ridynno-kistoznykh utvorenniakh pidshlunkovoi zalozy [Tactics of diagnosis and treatment in liquid-cystic growth in pancreatic gland]. Klinichna khirurhiia - Clinical Surgery, 86 (3), 3-6 [in Ukrainian].

5. Alsfasser, G., Schwandner, F., Pertschy, A., Hauenstei, K., Foitzik, T., Klar, E. (2012). Treatment of necrotizing pancreatitis, redefining the role of surgery. World J. Surg., 36 (5), 1142-1147.

6. Banks, P.A., Bollen T.L., Dervenis C., Gooszen, H.G., Johnson, C.D., \& Sarr M.G. (2013). Classification of acute pancreatitis 2012, revision of the Atlanta classification and definitions by international consensus. Gut., 62 (1), 102-111.

7. Working Group IAP/APA Acute Pancreatitis Guidelines. IAP/APA evidence-based guidelines for the management of acute pancreatitis. (2013). Pancreatology, 13 (1), 1-15.

8. Rotar, O., Khomiak, I., Nazarchuc, M., Rotar, V., Khomiak, A., Taneja, K., Railianu, S. (2019). Utility of Presepsin for diagnosis of infected acute necrotizing pancreatitis. JOP. J. Pancreas. (Online), 20 (2), 67-71

9. Shevchuk, I.M., Pylypchuk, V.I., Khrunik, A.D., \& Hedzik, S.M. (2017). Khirurhichne likuvannia khvorykh z pryvodu khronichnoho pankreatytu z biliarnoiu hipertenziieiu [Surgical treatment of chronic pancreatitis with biliary hypertension]. Klinichna khirurhiia - Clinical Surgery, 84 (8), 27-30 [in Ukrainian]. 10. Savoliuk, S.I., Svyrydiuk, B.V., \& Ivanko, O.V. (2018). Otsinka yakosti zhyttia khvorykh pokhyloho ta starechoho viku pislia miniinvazyvnykh operatyvnykh vtruchan z pryvodu hostroho kalkuloznoho kholetsystytu ta kholedokholitiazu [Estimation of quality of life in elderly and senile patients after miniinvasive operative interventions for an acute calculous cholecystitis and choledocholithiasis]. Klinichna khirurhiia-Clinical Surgery, 85 (9), 15-18 [in Ukrainian].

Отримано 26.11.2019 


\author{
I. V. KHOMIAK ${ }^{1}$, O. V. ROTAR ${ }^{2}$, A. I. KHOMIAK ${ }^{1}$, A. S. PALIANYTSIA², B. V. PETRIUK ${ }^{2}$ \\ O. Shalimov National Institute of Surgery and Transplantology ${ }^{1}$, Kyiv \\ Bukovinian State Medical University², Chernivtsi
}

\title{
TACTIC OF SURGICAL TREATMENT OF ACUTE NECROTIZING PANCREATITIS
}

The aim of the work: to estimate efficacy of proposed tactic of surgical treatment of acute necrotizing pancreatitis.

Materials and Methods. We analyzed results of treatment of 317 patients with acute necrotizing pancreatitis in whom proposed tactic of surgical interventions was used during 2013-2019. New onset of organ failure after operation, duration of intensive care treatment, postoperative complications and mortality rates were studied.

Results and Discussion. We used the step-up approach of surgical treatment which started from either diapeutic transcutaneous ultrasound-guided procedures in $48.2 \%$ and endoscopic ultrasound-guided - in $46.2 \%$ observations. Transcutaneous procedures were followed by less complication rate in acute necrotic collections cases whereas endoscopic interventions - in walled-off pancreatic necrosis patients. Wide laparotomic necrosectomies was applied in $14.5 \%$ of patients after 4th week from onset. Overall mortality rate was $3.5 \%$, after interventional treatment - $6.5 \%$. Application of step-up tactic of surgical treatment in patients with ANP decreases necessary in wide laparotomic necrosectomies and reduces level of postoperative complications.

Key words: acute necrotizing pancreatitis; minimally invasive procedures; echo-videoendoscopy; multimodal step-up tactic.

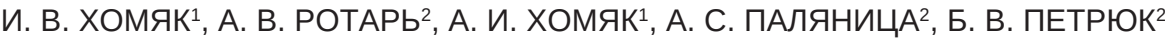

гу “Национальный институт хирургии и трансплантологии имени А. А. Шалимова" ${ }^{1}$, Киев ВГУЗ Украины “Буковинский государственный медицинский университет"2

\section{ХИРУРГИЧЕСКАЯ ТАКТИКА.ЛЕЧЕНИЯ ОСТРОГО НЕКРОТИЧЕСКОГО ПАНКРЕАТИТА}

Цель работы: оценить эффективность разработанной хирургической тактики лечения острого некротического панкреатита. Материалы и методы. Проведенный анализ результатов лечения 317 больных острым некротическим панкреатитом, у которых в течение 2013-2019 годов использовали предложенную тактику проведения хирургических вмешательств. Для оценки эффективности лечения изучали впервые обнаруженную органную недостаточность после операции, продолжительность интенсивной терапии, послеоперационные осложнения и летальность.

Результаты исследований и их обсуждение. Применяли пошаговую тактику хирургического лечения, которая начиналась с диапевтических транскутанных вмешательств у 48,2 \% и эндоскопических - в 46,2 \% наблюдений. Транскутанные вмешательства сопровождались меньшей частотой осложнений у больных с острыми некротическими скоплениями, а эндоскопические у пациентов с ограниченными очагами панкреатического некроза. Широкие лапаротомные некрсеквестрэктомии выполнялись у 14,5 \% наблюдений после 4 недели от начала заболевания. Общая летальность составила 3,5 \%, послеоперационная - 6,5 \%. Использование пошаговой хирургической тактики лечения больных острым некротическим панкреатитом уменьшает потребность в широких лапаротомных некрсеквестрэктомиях и способствует снижению уровня послеоперационных осложнений.

Ключевые слова: острый некротический панкреатит; миниинвазивные вмешательства; эхо-видеоэндоскопия; пошаговая тактика. 